\title{
Predictive Factors for Postoperative Decline in Renal Functions Following Partial Nephrectomy: Preliminary Results
}

\author{
Parsiyel Nefrektomi Sonrası Böbrek Fonksiyonlarındaki Postoperatif Azalmayı Belirleyici \\ Faktörler: Ön Sonuçlar
}

\author{
id İsmail Selvi ${ }^{1}$, iD Halil Başar2 \\ ${ }^{1}$ Karabük University Training and Research Hospital, Clinic of Urology, Karabük, Turkiye \\ 2 University of Health Sciences Dr. Abdurrahman Yurtaslan Ankara Oncology Training and Research Hospital, Clinic of Urology, Ankara, Turkiye
}

\section{What's known on the subject? and What does the study add?}

Partial nephrectomy is generally recommended for cT1 tumors over radical nephrectomy if surgically possible. Preserving the maximum possible renal parenchymal volume minimizes cardiovascular morbidity and non-cancer related death by preventing the development of chronic kidney disease. But there are still no validated clinical tools or nomograms for estimating short-term and long-term postoperative renal functions. In this study, we aimed to determine the risk factors associated with patient, tumor characteristics and surgical factors that may affect the decline in early-term and long-term eGFR levels during the follow-up period after partial nephrectomy.

\begin{abstract}
Objective: We aimed to determine the risk factors related to patient, tumor characteristics and surgery that may be associated with decline in renal function during follow-up after partial nephrectomy (PN).

Materials and Methods: Sixty-one patients who underwent PN due to localized stage la renal cell carcinoma between January 2010 and October 2018 were retrospectively analyzed. Demographic characteristics of the patients, clinical and pathological data, information about surgical techniques, preoperative score to predict postoperative mortality (POSPOM), Age-adjusted Charlson Comorbidity index (ACCI), Eastern Cooperative Oncology Group score, American Society of Anesthesiologists' score, preoperative estimated glomerular filtration rate (eGFR) and eGFR levels during postoperative follow-up were recorded.

Results: Twelve (19.7\%) patients experienced a decline in eGFR $\left(<60 \mathrm{~mL} / \mathrm{min} / 1.73 \mathrm{~m}^{2}\right)$ at the postoperative follow-up of median $30 \mathrm{months}$. Older age, higher Body Mass index, presence of hypertension, Diabetes Mellitus, tumor in the hilar region, higher scores of POSPOM, ACCI, RENAL and PADUA, lower preoperative eGFR, cold ischemia technique, total arterial clamping technique, longer warm ischemia time, longer cold ischemia time and lower preserved renal parenchymal volume (RPV) were found to be associated with both short- and long-term decline in eGFR ( $<60 \mathrm{~mL}$ ) $\min / 1.73 \mathrm{~m}^{2}$ ).

Conclusion: Although lower percentage of preserved RPV is a significant predictor of the postoperative deterioration of renal function, our results have shown that preoperative POSPOM score, ACCI and eGFR levels are just as important as surgical factors.

Keywords: Age-adjusted Charlson Comorbidity index, Estimated glomerular filtration rate, Partial nephrectomy, POSPOM score, Preserved renal parenchymal volume, Renal cell carcinoma
\end{abstract}

Öz

Amaç: Parsiyel nefrektomi (PN) sonrası takipte, böbrek fonksiyonlarındaki düşüşü etkileyebilecek hasta, tümör özellikleri ve cerrahi faktörlerle ilişkili risk faktörlerini belirlemeyi amaçladık.

Gereç ve Yöntem: Lokalize evre la renal hücreli karsinom nedeniyle Ocak 2010 ve Ekim 2018 arasında PN yapılan 61 hasta retrospektif olarak değerlendirildi. Hastaların demografik, klinik ve patolojik verileri, cerrahi tekniklerle ilgili bilgiler, "Preoperative score to Predict Postoperative Mortality" (POSPOM) skoru, Yaşa Göre Düzeltilmiş Charlson Komorbidite indeksi (ACCI), "Eastern Cooperative Oncology Group" skoru, "American

Correspondence: İsmail Selvi MD, Karabük University Training and Research Hospital, Clinic of Urology, Karabük, Turkiye

Phone: +90 03704158000 E-mail: ismselvi33@hotmail.com ORCID-ID: orcid.org/0000-0003-3578-0732

Received: 30.11 .2019

Accepted: 12.01 .2020

Cite this article as: Selvi I, Başar H. Predictive Factors for Postoperative Decline in Renal Functions Following Partial Nephrectomy: Preliminary Results. Journal of Urological Surgery, 2020;7(2):92-102

๑Copyright 2020 by the Association of Urological Surgery / Journal of Urological Surgery published by Galenos Publishing House. 
Society of Anesthesiologists" skoru, preoperatif tahmini glomerüler filtrasyon hızı (eGFR) ve postoperatif takiplerde bakılan eGFR düzeyleri hesaplanarak kaydedildi.

Bulgular: Ortanca 30 aylık postoperatif takipte, hastaların 12'sinin $(\% 19,7)$ eGFR düzeylerinin $60 \mathrm{~mL} /$ dak/1,73 m²'nin altına düşmüş olduğu gözlendi. İleri yaş; yüksek vücut kitle indeksi; hipertansiyon ve diabetes mellitus varlığı; hiler bölge yerleşimli tümör olmaSı; POSPOM, ACCI, RENAL ve PADUA skorlarının yüksek olması; preoperatif düşük eGFR düzeyleri; soğuk iskemi tekniği; total arteryel klempleme tekniği; uzamış sıcak iskemi süresi; uzamış soğuk iskemi süresi ve korunmuş renal parankimal hacim (RPV) oranında azalma, hem erken dönem hem de uzun dönem eGFR'de azalma $\left(<60 \mathrm{~mL} /\right.$ dak/1,73 $\left.\mathrm{m}^{2}\right)$ ile ilişkili olarak bulundu.

Sonuç: Korunmuş RPV oranında azalma, postoperatif böbrek fonksiyonlarındaki düşme olasılığını belirlemede önemli bir belirleyici olsa da, sonuçlarımız preoperatif POSPOM skoru, ACCI ve eGFR düzeylerinin en az cerrahi faktörler kadar önemli olduğunu göstermektedir.

Anahtar Kelimeler: Yaşa göre düzeltilmiş Charlson Komorbidite indeksi, Tahmini glomerüler filtrasyon hızı, Parsiyel nefrektomi, POSPOM skoru, Korunmuş renal parankimal hacmi, Renal hücreli karsinom

\section{Introduction}

The detection rate of incidental renal cell carcinoma (RCC) has increased with the widespread use of radiological imaging techniques (1). These masses are generally incidentally found in small size and lower stage. RCC constitutes 2-3\% of all cancers and has a higher incidence in the sixth and seventh decades of life (2). In recent years, partial nephrectomy (PN) has become increasingly popular, especially in clinical stage I (CT1) tumors due to an improved understanding of the importance of nephronsparing approach in terms of both cardiovascular and overall survival in the postoperative period. Preserving the maximum possible renal function minimizes cardiovascular morbidity and non-cancer-related death by preventing the development of chronic kidney disease (CKD) (3). Therefore, $\mathrm{PN}$ is recommended for CT1 stage renal masses if surgically possible (2).

Tumor diameter and configuration are the most important guiding factors in the decision of partial or radical nephrectomy (RN) (4). In this stage, it is known that PN maintains functional nephron structure and has survival outcomes comparable to RN. The type of nephrectomy alone is not a determining factor to protect the maximum renal function. It has been reported in some studies that other additional factors related to tumor, patient and PN techniques may also have effects on renal functions in the postoperative period $(3,4,5)$. Preoperative predictive tools for estimating short-term and long-term postoperative renal functions can be useful in deciding surgery type in complex cT1 renal masses. This can also lead us to decide whether it is worth taking the complication risks and potential oncologic risks related to PN (3). However, there are still controversial views that need to be agreed upon $(3,5)$.

We aimed to determine the risk factors related with patient, tumor characteristics and surgery that may be associated with decline in renal functions during follow-up period after PN.

\section{Materials and Methods}

\section{Patient Selection}

After obtaining approval from the local ethics committee (protocol number: 77192459-050.99-E.10735) and written informed consent from the patients, the data of patients, who underwent open PN for localized stage la RCC between January 2010 and October 2018, were retrospectively analyzed. Patients with moderate/severe renal dysfunction [estimated glomerular filtration rate (eGFR) $\left.\left.<60 \mathrm{~mL} / \mathrm{min} / 1.73 \mathrm{~m}^{2}\right)\right]$ before nephrectomy, patients with a history of chronic renal failure, solitary kidney, previous RN or PN, congenital urinary system diseases, congenital or acquired renal atrophy and patients who have received chemotherapy or any nephrotoxic agents were excluded. A total of 61 patients with fully accessible data were included in the study.

Demographic characteristics, tumor side, tumor location, tumor size, histological tumor type, Fuhrman grade, presence of necrosis, and follow-up time after PN were recorded. eGFR levels were calculated using age, sex, race and preoperative creatinine levels via the formula of modification of diet in renal disease (6). An eGFR level over $60 \mathrm{~mL} / \mathrm{min} / 1.73 \mathrm{~m}^{2}$ was defined as normal or near-normal kidney function. Lower levels were classified as stage 3 or higher CKD (6). Presence of additional diseases, smoking history, preoperative American Society of Anesthesiologists" (ASA) score, preoperative Eastern Cooperative Oncology Group (ECOG) performance status, and presence of preoperative proteinuria (none/mild/moderate/severe) were also recorded. Age-adjusted Charlson Comorbidity index (ACCI), Preoperative score to predict postoperative mortality (POSPOM), RENAL nephrometry score, and PADUA score were evaluated using preoperative demographic and clinical data. Type of ischemia (cold, warm or off-clamp), cold or warm ischemia times, type of arterial clamping technique (segmental or total), for patients in whom ischemia was done, total operative time, amount of blood loss during operation and perioperative blood 
transfusion status were recorded. eGFR values of the patients were recorded on the first postoperative day, and also on the $1^{\text {st }}, 3^{\text {rd }}, 6^{\text {th }}$, and $12^{\text {th }}$ months. The eGFR value at the last check-up was also recorded.

In our clinical approach, type of ischemia (cold, warm or off-clamp) and arterial clamping technique (segmental or total) were decided according to tumor status and surgeon's preference at the time of operation. Intravenous (i.v.) mannitol was administered in all patients undergoing ischemia by clamping the renal pedicle.

\section{RENAL Nephrometry Score and PADUA Score}

These two scores categorize renal masses in terms of tumor complexity for surgical decision-making and evaluate the suitability of cT1 stage renal masses for PN. Both scores evaluate tumor size as maximal diameter, exophytic or endophytic properties of the tumor, nearness of tumor's deepest portion to the collecting system or renal sinus, and the location relative to the polar line. RENAL score classifies tumors into three risk groups in terms of PN feasibility: low-risk (score 4-6), intermediate-risk (score 7-9), and high-risk (score 10-12). According to PADUA score, tumors are stratified into low-risk (score 6-7), intermediate-risk (score 8-9), and high-risk groups (score $\geq 10)(7)$.

\section{Calculation of Renal Parenchymal Volume}

The volume of normal or pathological structures whose borders can be distinguished on computed tomography (CT) or magnetic resonance imaging images can be calculated by the Cavalieri method (8). Firstly, the volume to be calculated is divided into parallel slices of equal thickness. The cross-sectional surface area of each slice is found and multiplied by the thickness of the slice to calculate the volume of each slice. The total volume of the structure is calculated by adding the volumes of each slices. We calculated renal parenchymal volume (RPV) on preoperative and postoperative CT images by this method. In addition, the percent change of RPV was calculated as follows:

(preoperative RPV - postoperative RPV) / preoperative RPV $\times$ $100 \%$.

\section{Age-adjusted Charlson Comorbidity Index}

This index is used to predict 30-day mortality in patients with trauma or diseases requiring immediate radical surgical intervention (9). Presence and severity of 19 different comorbidities (such as cardiovascular, pulmonary, gastrointestinal, urological, neurological or hematological diseases) are evaluated. For each parameter, a total score is formed by giving scores between 1 and 6 . In each case over the age of fifty, one more point is added for each decade.

\section{Preoperative score to Predict Postoperative Mortality}

It is a risk score that can predict the probability of in-hospital mortality, evaluate general health status of the patient and help physicians make clinical decisions for patients before surgery. Seventeen predictive factors including age, cardiovascular, cerebrovascular, pulmonary, nephrologic, urologic, endocrine and oncologic pathologies are defined in this scoring system. A total score of greater than 28 indicates a worse prognosis (10).

\section{Eastern Cooperative Oncology Group Performance Status}

This scale assesses the overall well-being of oncology patients. This scale is scored from 0 to 5 with 0 indicating normal health status and 5 - death (11).

\section{American Society of Anesthesiologists Physical Status Classification System}

This system was defined in 1941 by the ASA. It is used to assess and classify a patient's preoperative physical health status from 0 to 4 according to possible perioperative risks (12).

\section{Statistical Analysis}

Normality of continuous variables was evaluated using the Kolmogorov-Smirnov and Shapiro-Wilk tests. Normally distributed variables were expressed as mean \pm standard deviation. Non-normally distributed variables were expressed as median $\left(25^{\text {th }}\right.$ percentile $-75^{\text {th }}$ percentile). Binary logistic regression analysis was used to determine the predictive factors for declines in eGFR values. Spearman's correlation coefficient was used for determining correlations between postoperative loss of eGFR and the other parameters. In the postoperative period, survival time without stage $\geq 3$ chronic kidney disease was analyzed by the Kaplan-Meier method and differences between patient subgroups were evaluated by the log-rank test. A $p$ value of $<0.05$ was considered statistically significant. All statistical analyses were performed using the IBM SPSS Statistics 23 (IBM, Armonk, NY USA).

\section{Results}

A total of 61 patients with complete data and a median age of 59 (range 35-73) years were included in this study. Patient and tumor characteristics are shown in Table 1. Changes in eGFR at postoperative follow-up are shown in Figure 1. No significant difference was observed between the eGFR values at the postoperative $12^{\text {th }}$ month and the last eGFR values during the median follow-up of 30 months follow-up ( $p=0.879)$, but there were significant differences between the eGFR values in all other time periods $(p<0.001)$.

In the multivariate analysis for estimating both short-term eGFR within postoperative 30 days and long-term eGFR beyond 30 


\begin{tabular}{|c|c|}
\hline Parameters & Patients $(n=61)$ \\
\hline $\begin{array}{l}\text { Age } \\
(\min -\max )\end{array}$ & $\begin{array}{l}59.00(50.00-66.00) \\
35-73\end{array}$ \\
\hline $\begin{array}{l}\text { Gender }(n, \%) \\
\text {-Male } \\
\text {-Female }\end{array}$ & $\begin{array}{l}41(67.2) \\
20(32.8)\end{array}$ \\
\hline Body Mass index $\left(\mathrm{kg} / \mathrm{m}^{2}\right)$ & $23.96 \pm 3.26$ \\
\hline $\begin{array}{l}\text { Smoking }(n, \%) \\
\text {-Yes } \\
\text {-No }\end{array}$ & $\begin{array}{l}35(57.4) \\
26(42.6)\end{array}$ \\
\hline $\begin{array}{l}\text { Hypertension }(\mathbf{n}, \%) \\
\text {-Yes } \\
\text {-No }\end{array}$ & $\begin{array}{l}27(44.3) \\
34(55.7)\end{array}$ \\
\hline $\begin{array}{l}\text { Diabetes Mellitus }(n, \%) \\
\text {-Yes } \\
\text {-No }\end{array}$ & $\begin{array}{l}16(26.2) \\
45(73.8)\end{array}$ \\
\hline POSPOM score & $20.00(12.00-30.00)$ \\
\hline Preoperative Age-adjusted Charlson score & $5.00(4.00-7.00)$ \\
\hline $\begin{array}{l}\text { Preoperative ECOG score }(n, 0) \\
-0 \\
-1 \\
-2\end{array}$ & $\begin{array}{l}38(62.3) \\
20(32.8) \\
3(4.9) \\
\end{array}$ \\
\hline $\begin{array}{l}\text { Preoperative ASA score }(n, 0) \\
-1 \\
-2 \\
-3\end{array}$ & $\begin{array}{l}11(18.0) \\
28(45.9) \\
22(36.1)\end{array}$ \\
\hline $\begin{array}{l}\text { Tumor side }(n, \%) \\
\text {-Right } \\
\text {-Left }\end{array}$ & $\begin{array}{l}24(39.3) \\
37(60.7) \\
\end{array}$ \\
\hline $\begin{array}{l}\text { Tumor localization }(n, \%) \\
\text { Upper pole } \\
\text { Middle pole } \\
\text { Lower pole } \\
\text { Hilar }\end{array}$ & $\begin{array}{l}20(32.8) \\
11(18.0) \\
27(44.3) \\
3(4.9) \\
\end{array}$ \\
\hline Radiological tumor size (cm) & $3.00(2.50-3.37)$ \\
\hline $\begin{array}{l}\text { Preoperative proteinuria }(n, \%) \\
\text {-None } \\
\text {-Mild }(+1) \\
\text {-Moderate }(+2)\end{array}$ & $\begin{array}{l}53(86.9) \\
5(8.2) \\
3(4.9) \\
\end{array}$ \\
\hline RENAL score & $4.00(4.00-5.50)$ \\
\hline PADUA score & $7.00(6.00-7.00)$ \\
\hline Pathological tumor size $(\mathrm{cm})$ & $3.50(2.50-3.80)$ \\
\hline $\begin{array}{l}\text { Histological subtype }(\mathbf{n}, \%) \\
\text {-Clear cell } \\
\text {-Papillary type } 1 \\
\text {-Papillary type } 2 \\
\text {-Chromophobe }\end{array}$ & $\begin{array}{l}48(78.7) \\
8(13.1) \\
3(4.9) \\
2(3.3)\end{array}$ \\
\hline $\begin{array}{l}\text { Fuhrman grade }(n, \%) \\
-1 \\
-2 \\
-3 \\
-4\end{array}$ & $\begin{array}{l}16(26.2) \\
20(32.8) \\
24(39.3) \\
1(1.6)\end{array}$ \\
\hline
\end{tabular}

\begin{tabular}{|c|c|}
\hline $\begin{array}{l}\text { Presence of necrosis }(\mathbf{n}, \%) \\
- \text { Yes } \\
- \text { No }\end{array}$ & $\begin{array}{l}13(21.3) \\
48(78.7)\end{array}$ \\
\hline $\begin{array}{l}\text { Preoperative eGFR } \\
\left(\mathrm{mL} / \mathrm{min} / 1.73 \mathrm{~m}^{2}\right)\end{array}$ & $82.16 \pm 12.99$ \\
\hline $\begin{array}{l}\text { Ischemia type }(n, \%) \\
\text {-Cold } \\
\text {-Warm } \\
\text {-Off-clamp }\end{array}$ & $\begin{array}{l}27(44.3) \\
23(37.7) \\
11(18.0)\end{array}$ \\
\hline $\begin{array}{l}\text { Arterial clamping technique }(\mathbf{n}, \%) \\
\text {-Segmental } \\
\text {-Total } \\
\text {-Off-clamp }\end{array}$ & $\begin{array}{l}18(29.5) \\
32(52.5) \\
11(18.0)\end{array}$ \\
\hline $\begin{array}{l}\text { Hemostatic agents, }(n, \%) \\
\text { - Not used } \\
\text { - Used }\end{array}$ & $\begin{array}{l}19(31.1) \\
42(68.9)\end{array}$ \\
\hline Warm ischemia time (min) & $17.17 \pm 2.98$ \\
\hline Cold ischemia time (min) & $23.04 \pm 2.12$ \\
\hline Total operation time (min) & $\begin{array}{l}135.00(125.00-145.00) \\
(105-200)\end{array}$ \\
\hline $\begin{array}{l}\text { The amount of blood loss during } \\
\text { operation }(\mathrm{mL})\end{array}$ & $\begin{array}{l}200(100-250) \\
(50-410)\end{array}$ \\
\hline $\begin{array}{l}\text { Blood transfusion status }(n, \%) \\
- \text { Yes } \\
- \text { No }\end{array}$ & $\begin{array}{l}4(6.6) \\
57(93.4)\end{array}$ \\
\hline $\begin{array}{l}\text { Clavien- dindo classification }(n, \%) \\
-1 \\
-2 \\
-3 a\end{array}$ & $\begin{array}{l}20(32.7) \\
11(18.0) \\
3(4.9)\end{array}$ \\
\hline $\begin{array}{l}\text { eGFR level on the first postoperative } \\
\text { day } \\
\left(\mathrm{mL} / \mathrm{min} / 1.73 \mathrm{~m}^{2}\right)\end{array}$ & $76.04 \pm 12.27$ \\
\hline $\begin{array}{l}\text { eGFR level on the first postoperative } \\
\text { month }\left(\mathrm{mL} / \mathrm{min} / 1.73 \mathrm{~m}^{2}\right)\end{array}$ & $71.04 \pm 11.44$ \\
\hline $\begin{array}{l}\text { eGFR level on the } 3^{\text {rd }} \text { postoperative } \\
\text { month }\left(\mathrm{mL} / \mathrm{min} / 1.73 \mathrm{~m}^{2}\right)\end{array}$ & $66.79 \pm 11.27$ \\
\hline $\begin{array}{l}\text { eGFR level on the } 6^{\text {th }} \text { postoperative } \\
\text { month }\left(\mathrm{mL} / \mathrm{min} / 1.73 \mathrm{~m}^{2}\right)\end{array}$ & $69.11 \pm 11.55$ \\
\hline $\begin{array}{l}\text { eGFR level on the } 12^{\text {th }} \text { postoperative } \\
\text { month }\left(\mathrm{mL} / \mathrm{min} / 1.73 \mathrm{~m}^{2}\right)\end{array}$ & $71.10 \pm 11.91$ \\
\hline$\%$ eGFR preserved at the $12^{\text {th }}$ month & $86.60 \pm 5.74$ \\
\hline$\%$ eGFR loss at the $12^{\text {th }}$ month & $13.40 \pm 5.74$ \\
\hline Follow-up period (months) (min-max) & $30(24-57)(12-91)$ \\
\hline $\begin{array}{l}\text { The last eGFR level month } \\
\left(\mathrm{mL} / \mathrm{min} / 1.73 \mathrm{~m}^{2}\right)\end{array}$ & $71.08 \pm 11.67$ \\
\hline $\begin{array}{l}\text { The rate of decline in eGFR below } 60 \\
\mathrm{~mL} / \mathrm{min} / 1.73 \mathrm{~m}^{2}(\mathrm{n}, \%)\end{array}$ & $12(19.7)$ \\
\hline Preoperative RPV $\left(\mathrm{cm}^{3}\right)$ & $154.26 \pm 4.98$ \\
\hline Postoperative RPV $\left(\mathrm{cm}^{3}\right)$ & $132.43 \pm 7.11$ \\
\hline Preserved RPV ratio (\%) & $85.81 \pm 3.21$ \\
\hline Loss RPV ratio (\%) & $14.19 \pm 3.21$ \\
\hline \multicolumn{2}{|c|}{$\begin{array}{l}\text { ASA: American Society of Anesthesiologists', ECOG: Eastern Cooperative Oncology } \\
\text { Group, eGFR: Estimated glomerular filtration rate, POSPOM: Preoperative score to } \\
\text { Predict Postoperative Mortality; RPV: Renal parenchymal volume, cm: Centimeter } \\
\text { Follow-up period (months) min-max: Follow-up period (months) minimum-maximum } \\
\text { min: minute, mL: milliliter, Normally distributed datas are expressed as "mean } \\
\text { standard deviation", Non-normal distributed datas are expressed as "median }\left(25^{t}\right. \\
\text { percentile- } 75^{\text {th }} \text { percentile)" }\end{array}$} \\
\hline
\end{tabular}




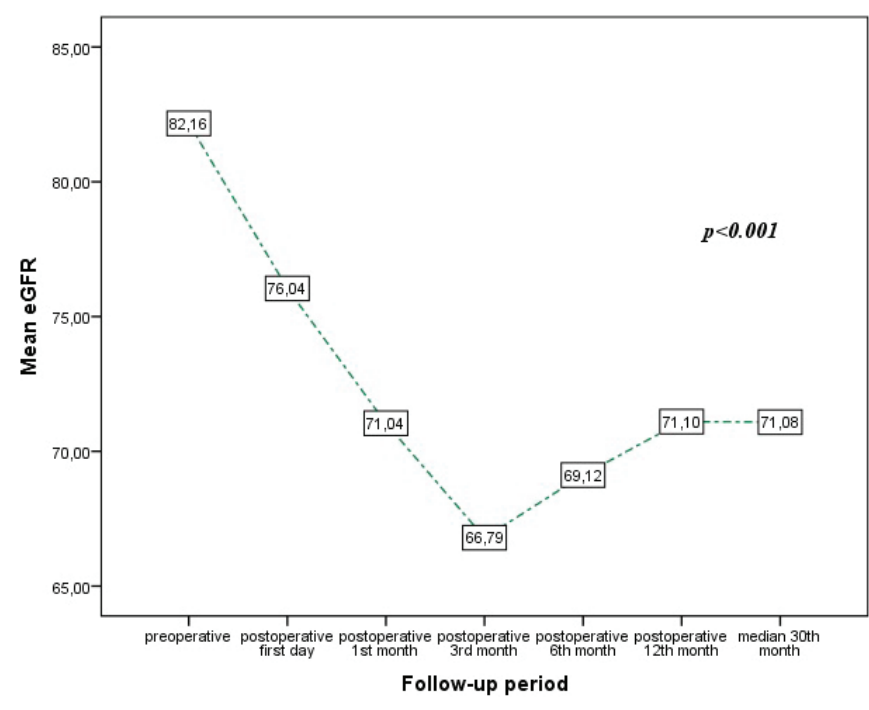

Figure 1. Changes in eGFR levels at postoperative follow-up eGFR: Estimated glomerular filtration rate

days, older age, higher BMI, presence of hypertension, diabetes mellitus, tumor location in the hilar region, higher scores of POSPOM, ACCI, RENAL and PADUA, lower preoperative eGFR, cold ischemia technique, total arterial clamping technique, longer warm ischemia time, longer cold ischemia time and lower percent preserved RPV were found to be associated with the declines in eGFR to $<60 \mathrm{~mL} / \mathrm{min} / 1.73 \mathrm{~m}^{2}$ (Table 2,3).

Due to the small sample size, ROC analysis could not be performed to determine the threshold value for these predictive factors in multivariate analysis. Instead, mean values for normally distributed variables and median values for non-normal distributed variables were determined. In this way, subgroups were created according to the median scores of POSPOM, ACCI, RENAL, PADU, and the mean values of the preserved RPV, warm ischemia time and cold ischemia time. survival time without stage $\geq 3$ chronic kidney disease were evaluated for these subgroups and are shown in Figure 2,3.

According to our results, loss of RPV had a strong positive relationship with RENAL score $(r=0.702, p<0.001)$ and PADUA score $(r=0.690, p<0.001)$. We also observed a strong positive correlation between the postoperative long-term loss of eGFR and POSPOM ( $r=0.609, p<0.001), A C C l(r=0.599, p<0.001)$. On the other hand, postoperative long-term loss of eGFR had a weak positive correlation with RENAL score $(r=0.367, p=0.038)$, PADUA score $(r=0.322, p=0.045)$ and loss of RPV $(r=0.335$, $p=0.048)$.

\section{Discussion}

It is known that the greater amount of preserved nephron during PN may reduce the development of CKD in the future (13). In a metaanalysis conducted by Mir et al. (14), 41.7\% of a total 1734 patients undergoing PN were found to have a postoperative increase in CKD stage. Stage 3 CKD $(30-60 \mathrm{~mL} /$ $\mathrm{min} / 1.73 \mathrm{~m}^{2}$ ) is seen in 20\% of cases after PN. In their study, Mason et al. (15) found that grade 4 and 5 CKD (eGFR $<30 \mathrm{~mL}$ ) $\min / 1.73 \mathrm{~m}^{2}$ ) developed in 4.1-5\% of 665 patients after PN. After nephrectomy, the simplest and safest predictor of preserved renal function is eGFR. According to current literature, PN preserves approximately $80 \%$ of the function in the operated kidney and $90 \%$ of global function (14). Our results were consistent with the literature. The preserved global renal function at the $12^{\text {th }}$ month was $86.6 \%$. Stage 3 CKD was observed in $19.7 \%$ of all patients.

PN is preferred as the standard approach for cT1 renal masses if technically feasible because it is believed that PN provides better renal functions and a potential overall survival benefit $(16,17)$. However, the European Organization for Research and Treatment of Cancer trial 30904 showed the superiority of RN versus PN in terms of 10 -year overall survival ( $81.1 \%$ vs. 75.7\%; hazard ratio $1.51, p=0.02$ ) (18). These findings state that protection of maximal renal unit following $\mathrm{PN}$ alone is not enough to provide better renal functions. However, there are still no validated clinical tools or nomograms for making this prediction $(3,16)$. Therefore, as an additional contribution to the literature, we aimed to determine the predictors for decline in eGFR during follow-up period after PN.

Tumor size and location are strong determinants of parenchymal volume loss and ischemia time during PN. These factors are known to be very closely related to postoperative renal functions (17). Although preservation of the maximum amount of renal parenchyma may prevent excessive decline in eGFR in the postoperative period, it has been reported that the type of PN alone cannot be sufficient to achieve this (19). It is also known that decline in eGFR and preservation of long-term renal function depend on both surgical technique and preoperative medical comorbidities (20).

It has been reported that minimizing the duration of ischemia during PN reduced oxidative stress molecules after surgery, thus development of hyperfiltration renal damage could be prevented. Each additional minute of warm ischemia was found to be correlated with a 6\% increased incidence of de novo severe CKD (14). As a result, PN techniques without clamp, which completely removed this damage, have recently gained importance. On the other hand, Greco et al. (21) evaluated the effect of cold, warm, and off-clamp ischemia on postoperative eGFR loss. They could not recommend any of the available ischemia techniques versus the others. However, we observed that cold ischemia increased long-term eGFR decline by 1.24 times compared to off-clamp ischemia. Moreover, longer durations of warm and cold ischemia increased renal deterioration by 2.12 and 1.90 times, respectively. 
Various studies have reported that use of i.v. mannitol during PN, total operative time, blood loss, and additional comorbidities (hypertension, diabetes, etc.) may affect postoperative eGFR $(22,23)$. However, there are also contradictory views that these factors cannot be as effective as protected RPV $(17,24)$. Among these factors, we found presence of hypertension and diabetes to be predictors for postoperative renal functions.

Table 2. Predictive factors for decline in early-term estimated glomerular filtration rate to $<60 \mathrm{~mL} / \mathrm{min} / 1.73 \mathrm{~m}{ }^{2}$ within 30 days after surgery postoperatively

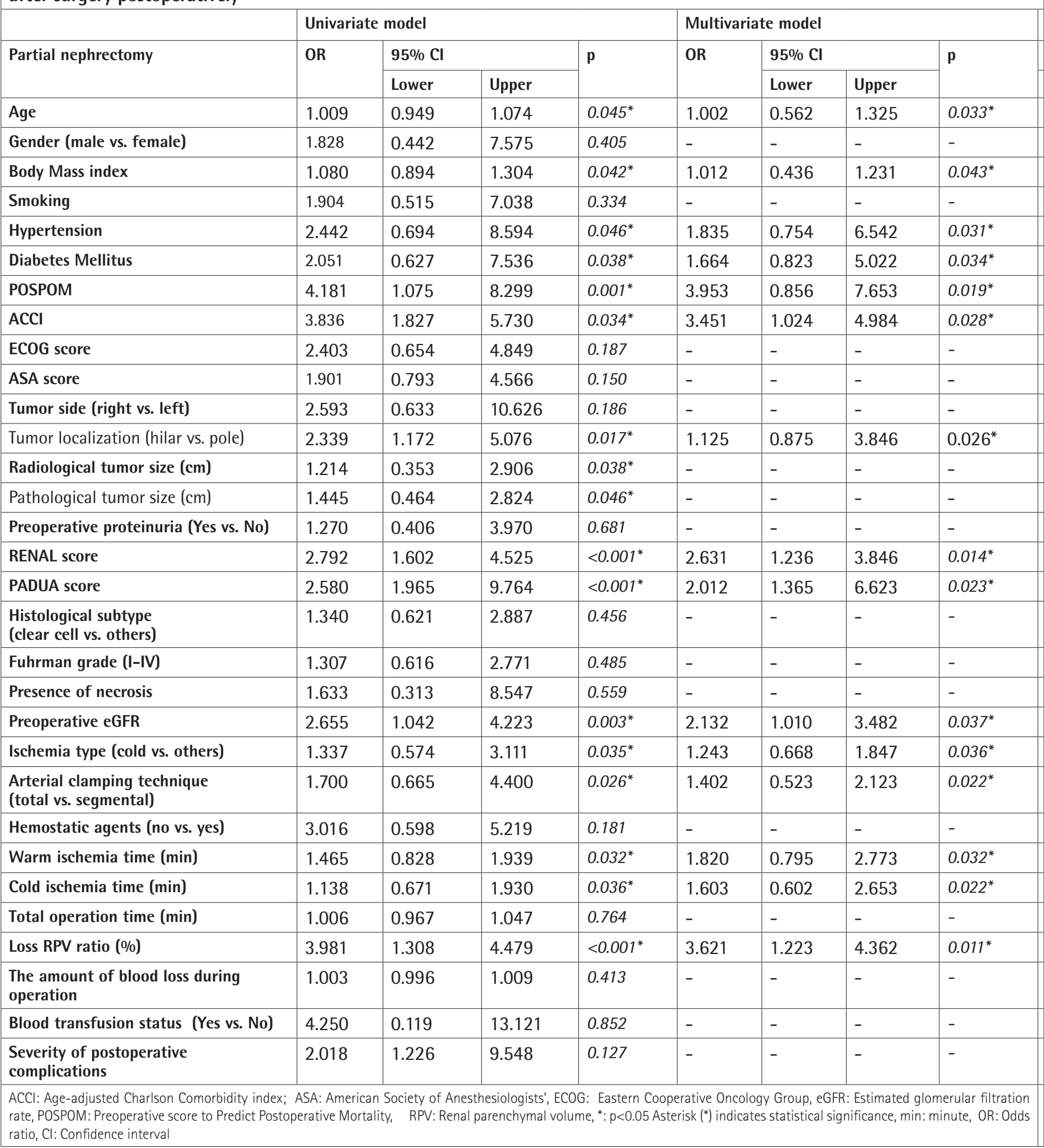




\begin{tabular}{|c|c|c|c|c|c|c|c|c|}
\hline \multirow{3}{*}{ Partial nephrectomy } & \multicolumn{4}{|c|}{ Univariate model } & \multicolumn{4}{|c|}{ Multivariate model } \\
\hline & \multirow[t]{2}{*}{ OR } & \multicolumn{2}{|l|}{$95 \% \mathrm{Cl}$} & \multirow[t]{2}{*}{$\mathbf{p}$} & \multirow[t]{2}{*}{ OR } & \multicolumn{2}{|l|}{$95 \% \mathrm{Cl}$} & \multirow[t]{2}{*}{$\mathbf{p}$} \\
\hline & & Lower & Upper & & & Lower & Upper & \\
\hline Age & 1.051 & 0.979 & 1.129 & $0.041^{*}$ & 1.026 & 0.771 & 1.132 & $0.038^{*}$ \\
\hline Gender (male vs. female) & 1.594 & 0.380 & 6.666 & 0.524 & - & - & - & - \\
\hline Body Mass index & 1.123 & 0.922 & 1.366 & $0.029^{*}$ & 1.108 & 0.687 & 1.147 & $0.039^{*}$ \\
\hline Smoking & 2.654 & 0.640 & 11.001 & 0.179 & - & - & - & - \\
\hline Hypertension & 2.158 & 0.835 & 10.949 & $0.042^{*}$ & 1.987 & 1.121 & 3.027 & $0.029^{*}$ \\
\hline Diabetes Mellitus & 2.854 & 0.573 & 9.666 & $0.047^{*}$ & 2.031 & 1.203 & 3.012 & $0.024^{*}$ \\
\hline POSPOM & 4.863 & 1.142 & 9.627 & $0.001^{*}$ & 4.123 & 1.026 & 8.435 & $0.015^{*}$ \\
\hline $\mathrm{ACCl}$ & 3.958 & 1.725 & 5.485 & $0.038^{*}$ & 3.026 & 1.202 & 4.139 & $0.021^{*}$ \\
\hline ECOG score & 1.035 & 0.349 & 3.067 & 0.550 & - & - & - & - \\
\hline ASA score & 1.265 & 0.525 & 3.048 & 0.790 & - & - & - & - \\
\hline Tumor side (right vs. left) & 1.379 & 0.365 & 5.208 & 0.635 & - & - & - & - \\
\hline Tumor localization (hilar vs. pole) & 2.188 & 1.052 & 4.545 & $0.036^{*}$ & 1.385 & 0.652 & 2.658 & $0.042^{*}$ \\
\hline Radiological tumor size $(\mathrm{cm})$ & 2.043 & 0.452 & 4.409 & $0.029^{*}$ & - & - & - & - \\
\hline Pathological tumor size $(\mathrm{cm})$ & 2.270 & 0.638 & 4.525 & $0.045^{*}$ & - & - & - & - \\
\hline Preoperative proteinuria (yes vs. no) & 1.074 & 0.289 & 3.984 & 0.915 & - & - & - & - \\
\hline RENAL score & 3.369 & 2.550 & 12.916 & $0.006^{*}$ & 2.031 & 1.184 & 3.953 & $0.032^{*}$ \\
\hline PADUA score & 2.678 & 1.466 & 4.061 & $0.039^{*}$ & 1.853 & 1.236 & 3.187 & $0.040^{*}$ \\
\hline $\begin{array}{l}\text { Histological subtype } \\
\text { (clear cell vs. others) }\end{array}$ & 1.430 & 0.660 & 3.094 & 0.364 & - & - & - & - \\
\hline Fuhrman grade (I-IV) & 1.005 & 0.471 & 2.144 & 0.919 & - & - & - & - \\
\hline Presence of necrosis & 1.447 & 0.275 & 7.633 & 0.662 & - & - & - & - \\
\hline Preoperative eGFR & 2.355 & 1.137 & 4.612 & $0.001^{*}$ & 2.230 & 1.014 & 3.685 & $0.031^{*}$ \\
\hline Ischemia type (cold vs. others) & 1.594 & 0.665 & 3.824 & $0.026^{*}$ & 1.243 & 0.668 & 1.847 & $0.036^{*}$ \\
\hline $\begin{array}{l}\text { Arterial clamping technique } \\
\text { (total vs. segmental) }\end{array}$ & 1.711 & 0.665 & 4.400 & $0.026^{*}$ & 1.423 & 0.552 & 3.452 & $0.014^{*}$ \\
\hline Hemostatic agents (no vs. yes) & 1.455 & 0.346 & 6.118 & 0.609 & - & - & - & - \\
\hline Warm ischemia time (min) & 2.630 & 0.935 & 3.843 & $0.038^{*}$ & 2.125 & 1.342 & 3.589 & $0.024^{*}$ \\
\hline Cold ischemia time (min) & 2.217 & 1.765 & 4.935 & $0.027^{*}$ & 1.901 & 1.215 & 2.570 & $0.032^{*}$ \\
\hline Total operation time (min) & 1.017 & 0.980 & 1.056 & 0.369 & - & - & - & - \\
\hline Loss RPV ratio (\%) & 4.739 & 1.576 & 14.252 & $0.006^{*}$ & 4.023 & 1.240 & 12.356 & $0.008^{*}$ \\
\hline $\begin{array}{l}\text { The amount of blood loss during } \\
\text { operation }\end{array}$ & 1.006 & 0.699 & 1.912 & 0.104 & - & - & - & - \\
\hline Blood transfusion status (yes vs. no) & 4.700 & 0.590 & 7.449 & 0.144 & - & - & - & - \\
\hline $\begin{array}{l}\text { Severity of postoperative } \\
\text { complications }\end{array}$ & 1.382 & 0.876 & 2.317 & 0.118 & - & - & - & - \\
\hline
\end{tabular}

In patients undergoing $\mathrm{PN}$, older age, presence of solitary kidney, hypertension, lower preoperative eGFR, preoperative proteinuria, and open surgical approach were found to be associated with worse long-term eGFR beyond 30 days postoperatively. Besides these factors, black/African-American race, higher ECOG score $(\geq 1)$, diabetes and larger tumor size were found to be predictors for the development of CKD stage 4-5 within 30 days after PN (3). Other known risk factors for decline in postoperative eGFR 

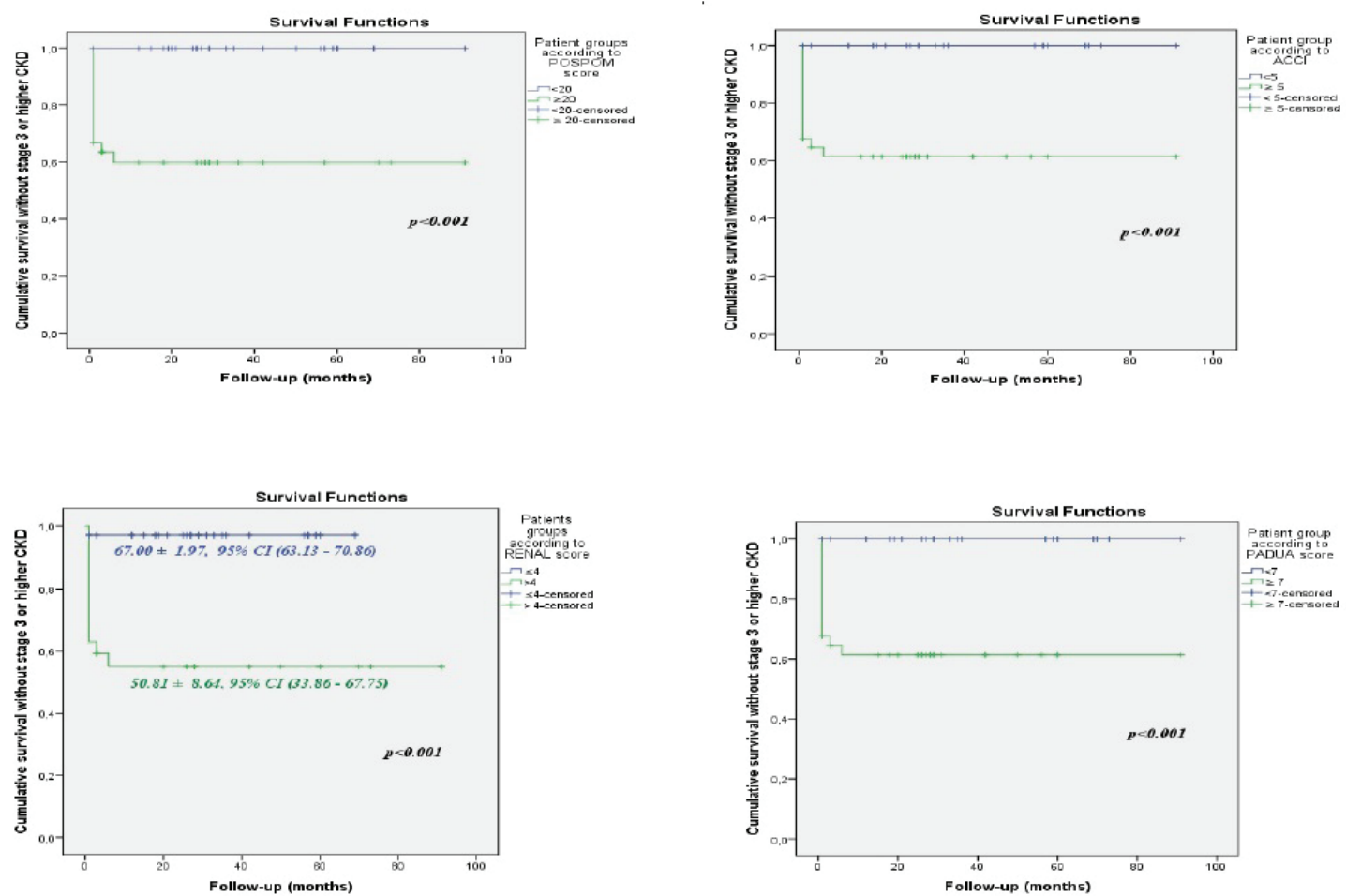

Figure 2. Survival time without stage $\geq 3$ chronic kidney disease according to POSPOM score, Age-adjusted Charlson Comorbidity index, RENAL score and PADUA score

POSPOM: Preoperative score to Predict Postoperative Mortality
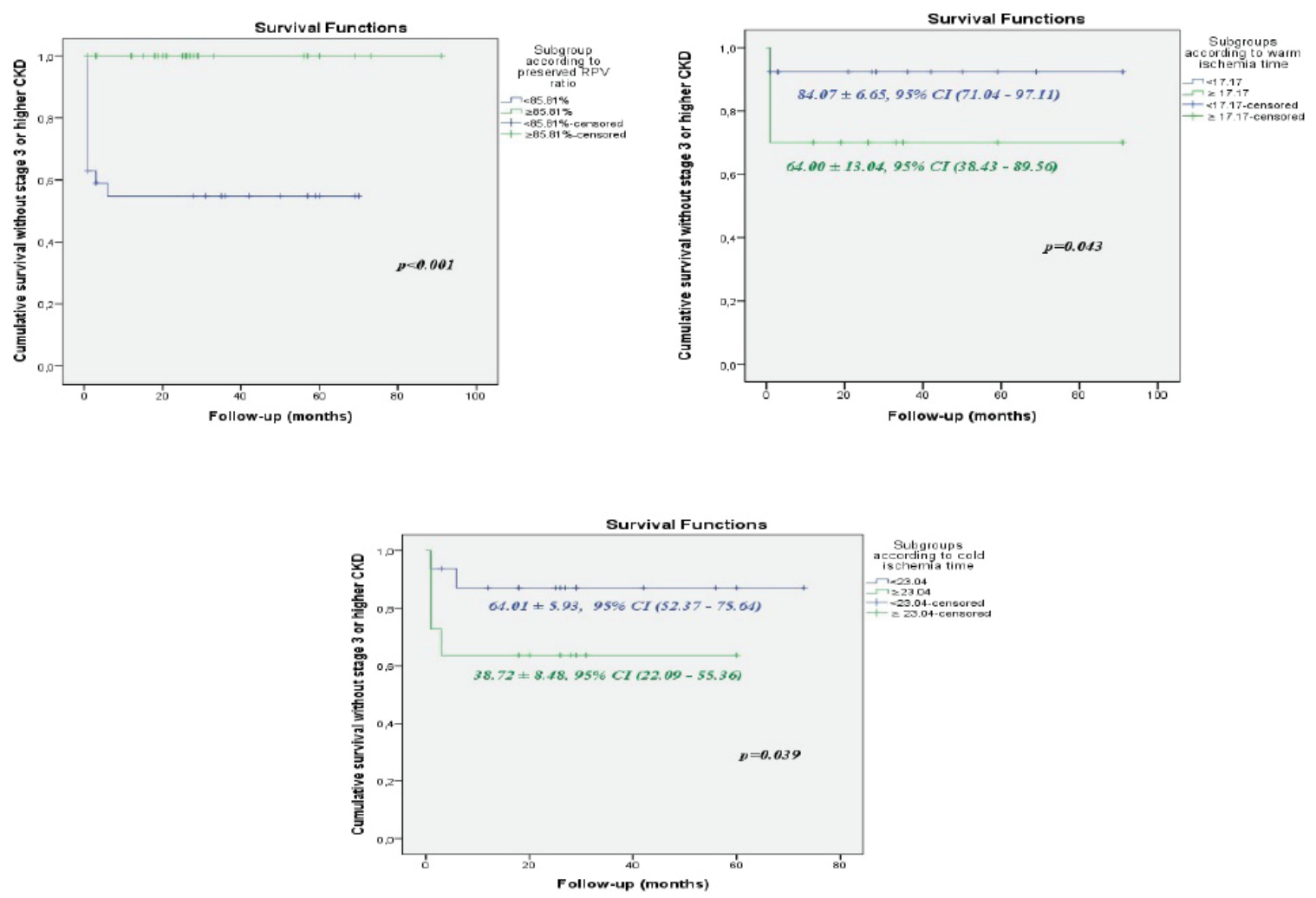

Figure 3. Survival time without stage $\geq 3$ chronic kidney disease according to preserved renal parenchymal volume ratio, warm ischemia time and cold ischemia time 
to $\leq 45 \mathrm{~mL} / \mathrm{min} / 1.73 \mathrm{~m}^{2}$ regardless of nephrectomy type (PN or $\mathrm{RN}$ ) are female gender, peripheral vascular disease, increased preoperative creatinine level and longer ischemia time $(16,20)$. Contrary, some studies did not find an effect of tumor size and ischemia type and duration on postoperative renal functions $(15,25)$.

In our study, we found that higher percentage of preserved RPV and also RENAL and PADUA scores which indicate tumor complexity, were more important predictors for a decline in eGFR than tumor size and stage. In addition, the most important predictors of decline in eGFR were higher POSPOM score, lower percent of preserved RPV, higher $\mathrm{ACCl}$, and lower preoperative eGFR. We observed that POSPOM and $\mathrm{ACCl}$ are more predictive parameters than each comorbidity that constitutes them. Bhindi et al. (3) showed the effects of hypertension and diabetes that were parameters in these two indices, on renal functions. According to their results, nephron-sparing alone was not sufficient to protect renal function in diabetic nephropathy. In addition, postoperative blood glucose regulation was also essential. We also found a similar effect of hypertension and diabetes, but high POSPOM and ACCI scores were found to have more comprehensive effects on postoperative renal functions. Similar to the results of Winer et al. (20), in our multivariate analysis, ECOG score and ASA score did not predict postoperative renal functions, although they were morbidity indices.

Sejima et al. (26) used a high-speed three-dimensional image analysis system to create reconstructed renal volumetric images via CT. They found a strong positive correlation between postoperative eGFR and preserved RPV. Mir et al. (17) performed a similar volumetric analysis and found that the preserved eGFR in the operated kidney was 79\%. This rate was associated with higher percent of preserved RPV, lower RENAL score and the use of hypothermia. Contrary to the common opinion, they did not find any correlation between ischemia time and preserved kidney function (17). Other studies supporting this finding showed that parenchymal volume loss was a stronger determinant of decline in renal function rather than warm ischemia time $(27,28)$. In our study, we calculated the preserved RPV by using the Cavalieri method instead of three-dimensional imaging systems. Although three-dimensional imaging systems can make more precise calculations, the Cavalieri method is much easier in practice and often takes less time. We also used RENAL and PADUA scores which evaluate the complexity of the tumor. In this way, we tried to make a prediction for renal function changes during the postoperative follow-up period by using them. We found that loss of RPV, high RENAL and PADUA scores increased the decline in eGFR by 4.02, 2.03 and 1.85 times, respectively. We also observed that prolonged warm and cold ischemia times caused a 2.12 and 1.90-fold increase in eGFR reduction, respectively. Contrary to the results of Lane et al. (27) and Simmons et al. (28), we can say that high RENAL and PADUA scores, which enable us to indirectly predict renal parenchymal loss, have a similar effect on renal function reduction as prolonged ischemia times have. In many studies, following an initial decline in eGFR within postoperative 3 months, a slight increase and stabilization were observed within average 12 months $(20,29)$. Decreases in eGFR values in the first 3 months may be due to transient postoperative acute kidney injury (30). According to our findings, changes in eGFR during postoperative follow-up were similar. The improvements in renal functions were reported to last for up to five years after surgery (30).

PN was performed by the same surgical team in all patients included in our study. Although different surgical techniques have been performed, there was no difference in terms of surgical skills. In addition to the previous studies, we investigated the effects of results of different indices associated with preoperative comorbidities on postoperative renal functions. We have detected that in long-term evaluation, higher POSPOM score (OR: 4.12), higher ACCI (OR: 3.02) and lower preoperative eGFR (OR: 2.23) were more important risk factors than other parameters related to surgery except for preserved RPV (OR: 4.02). We also observed similar results in the short-term 30day follow-up. As a result, it may be considered that medical comorbidities increase the nephron's susceptibility to surgical damage. Similar to our results, Mason et al. (15) observed that surgical renal failure had a lower propensity for progressive renal disease rather than medical renal failure.

\section{Study Limitations}

Our main limitation was a retrospective, nonrandomized design with a limited number of patients in a single center. Secondly, we could not evaluate preoperative and postoperative split renal functions. As a result, changes in operated kidney and contralateral kidney could not be separately evaluated. Instead, total renal functions were evaluated. Thirdly, although we evaluated renal functions in the first postoperative 12 months for each patient, we could not reach long-term follow-up results for all patients. Instead, we reported results of a median 30-month follow-up, so it is another limitation. Furthermore, we used the Cavalieri method instead of three-dimensional imaging systems for the volumetric analysis of preserved renal parenchyma. It can be considered a limitation. Finally, we could not evaluate the effect of minimally-invasive techniques on the decline in eGFR because we have no laparoscopic or robotic surgery experiences.

\section{Conclusion}

Preoperative POSPOM score, ACCl, and eGFR levels are just as important as surgical factors in determining the probability 
of decline in renal function according to our results. Although our findings may provide some important predictions, we present them as "preliminary results" because it is not easy to have comprehensive results due to our study limitations. More advanced and validated predictive nomograms are needed to presume short-term and long-term renal functions.

\section{Ethics}

Ethics Committee Approval: The study was approved by the local ethics committee (the protocol number: 77192459-050.99E.10735; the date of approval: October 8, 2019) at Karabük University Training and Research Hospital. All procedures performed in our study involving human participants were in accordance with the ethical standards of the institutional and national research committee and with the 1964 Helsinki Declaration and its later amendments or comparable ethical standards.

Informed Consent: Patients were pre-operatively informed about the use of oncologic follow-up data in various oncological studies without revealing patient names and identity information. A formal written informed consent was obtained from all individual participants included in the study. The data of patients who did not consent was not used.

Peer-review: Externally peer-reviewed.

\section{Authorship Contributions}

Concept: i.S., H.B., Design: I.S., H.B., Data Collection or Processing: i.S., Analysis or Interpretation: I.S., H.B., Literature Research: I.S., Writing: i.S.

Conflict of Interest: No conflict of interest was declared by the authors.

Financial Disclosure: The authors declared that this study received no financial support.

\section{References}

1. Rendon RA, Kapoor A, Breau R, Leveridge $M$, Feifer A, Black PC, So A. Surgical management of renal cell carcinoma: Canadian Kidney Cancer Forum Consensus. Can Urol Assoc J 2014;8:E398-412.

2. Ljungberg B, Albiges L, Bensalah K, Bex A, Giles RH, Hora M, Kuczyk MA, Kuusk T, Lam TM, Marconi L, Merseburger AS, Powles T, Staehler M, Tahbaz R, Vope A, Bex A. European Association of Urology guidelines on renal cell carcinoma: the 2019 Update. Eur Urol 2019;75:799-810.

3. Bhindi B, Lohse CM, Schulte PJ, Mason RJ, Cheville JC, Boorjian SA, Leibavich BC, Thampson H. Predicting Renal Function Outcomes After Partial and Radical Nephrectomy. Eur Urol 2019;75:766-772.

4. Tobert CM, Kahnoski RJ, Thompson DE, Anema JG, Kuntzman RS, Lane BR. RENAL nephrometry score predicts surgery type independent of individual surgeon's use of nephron sparing surgery. Urology 2012;80:157-161.

5. Shum CF, Bahler CD, Cary C, Masterson TA, Boris RS, Gardner TA Kaimakliotis HZ, Foster RS, Bihrle R, Koch MO, JR JES, Sundaram CP.
Preoperative nomograms for predicting renal function at 1 year after partial nephrectomy. J Endourol 2017;31:711-718.

6. Yildiz G, Mağden K, Abdulkerim Y, Ozcicek F, Hür E, Candan F. Glomerular filtration rate: which method should we measure in daily clinical practice? Minerva Med 2013;104:613-623.

7. Schiavina R, Novara G, Borghesi M, Ficarra V, Ahlawat R, Moon DA, Porpiglia F, Challacombe BJ, Dasgupta P, Brunocilla E, La Manna G, Volpe A, Verma $H_{\text {, }}$ Martorana G, Mottrie A. PADUA and R.E.N.A.L. nephrometry scores correlate with perioperative outcomes of robot-assisted partial nephrectomy: analysis of the Vattikuti Global Quality Initiative in Robotic Urologic Surgery (GQIRUS) database. BJU Int 2017;119:456-463.

8. Kabay S, Ozden H, Yucel M, Tefekli AH, Gulbandilar E, Muslumanoglu AY. Estimation of the Tumor Volume and Volume Ratio on Computed Tomography in Patients with Renal Cell Carcinoma: A Stereological Study. Journal of Health Science 2007:53:664-670.

9. St-Louis E, Iqbal S, Feldman LS, Sudarshan M, Deckelbaum DL, Razek TS, Khwaja K. Using the age-adjusted Charlson comorbidity index to predict outcomes in emergency general surgery. J Trauma Acute Care Surg 2015;78:318-323.

10. Le Manach Y, Collins G, Rodseth R, Le Bihan-Benjamin C, Biccard B, Riou B, Devereaux PJ, Landais P. Preoperative Score to Predict Postoperative Mortality (POSPOM): Derivation and Validation. Anesthesiology 2016:124:570-579.

11. Oken MM, Creech RH, Tormey DC, Horton J, Davis TE, McFadden ET, Paul C. Toxicity and response criteria of the Eastern Cooperative Oncology Group. Am J Clin Oncol 1982;5:649-655.

12. Saklad M. Grading of Patients for Surgical Procedures. Anesthesiology $1941 ; 2: 281-284$

13. Kambara T, Tanimoto R, Araki M, Saikab T, Hashimotod H, Oedae T, Tsushima $T$, Hayata S, Nasu Y, Kobayashi Y. Renal function after nephrectomy influences the risk of cardiovascular events. Acta Med Okayama 2018;72:241-247.

14. Mir MC, Ercole C, Takagi T, Zhang Z, Velet L, Remer EM, Demirjian S, Campbell SC. Decline in renal function after partial nephrectomy: etiology and prevention. J Urol 2015;193:1889-1898.

15. Mason R, Kapoor A, Liu Z, Saarela O, Tanguay S, Jewett M, Finelli A, Lacombe L, Kawakami J, Moore R, Morash C, Black P, Rendon RA. The natural history of renal function after surgical management of renal cell carcinoma: Results from the Canadian Kidney Cancer Information System. Urol Oncol 2016;34:486.e1-486.e7.

16. Mcintosh AG, Parker DC, Egleston BL, Uzzo RG, Haseebuddin M, Joshi SS, Viterbo R, Greenberg RE, Chen DYT, Smaldone MC, Kutikov A. Prediction of significant estimated glomerular filtration rate decline after renal unit removal to aid in the clinical choice between radical and partial nephrectomy in patients with a renal mass and normal renal function. BJU Int 2019;124:999-1005.

17. Mir MC, Campbell RA, Sharma N, Remer EM, Simmons MN, Li J, Demirjian S, Kaouk J, Campbell SC. Parenchymal volume preservation and ischemia during partial nephrectomy: functional and volumetric analysis. Urology 2013;82:263-268.

18. Van Poppel H, Da Pozzo L, Albrecht W, Matveev V, Bono A, Borkowski A, Colombel M, Klotz L, Skinner E, Keane T, Marreaud S, Collette S, Sylvester R. A prospective, randomised EORTC intergroup phase 3 study comparing the oncologic outcome of elective nephron-sparing surgery and radical nephrectomy for low-stage renal cell carcinoma. Eur Urol 2011;59:543-552.

19. Zhang F, Gao S, Chen XN, Wu B. Clampless and sutureless laparoscopic partial nephrectomy using monopolar coagulation with or without N-butyl-2-cyanoacrylate. World J Surg Oncol 2019;17:72.

20. Winer AG, Zabor EC, Vacchio MJ, Hakimi AA, Russo P, Coleman JA, Jaimes EA. The Effect of Patient and Surgical Characteristics on Renal Function After Partial Nephrectomy. Clin Genitourin Cancer 2018;16:191-196. 
21. Greco F, Autorino R, Altieri V, Campbell S, Ficarra V, Gill I, Kutikov A, Mottrie A, Mirone V, Poppel HV. Ischemia Techniques in Nephron-sparing Surgery: A Systematic Review and Meta-Analysis of Surgical, Oncological, and Functional Outcomes. Eur Urol 2019;75:477-491.

22. Spaliviero M, Power NE, Murray KS, Sjoberg DD, Benfante NE, Bernstein ML, Wren J, Russo P, Coleman JA. Intravenous Mannitol Versus Placebo During Partial Nephrectomy in Patients with Normal Kidney Function: A Doubleblind, Clinically-integrated, Randomized Trial. Eur Urol 2018;73:53-59.

23. Breau RH, Cagiannos I, Knoll G, Morash C1, Cnossen S2, Lavallée LT, Mallick R, Finelli A, Jewett M, Leibovich BC, Cook J, LeBel L, Kapoor A, Poulot F, Izawa $J$, Rendon R, Fergusson DA. Renal hypothermia during partial nephrectomy for patients with renal tumours: a randomised controlled clinical trial protocol. BMJ Open 2019;9:e025662.

24. Klingler MJ, Babitz SK, Kutikov A, Campi R, Hatzichristodoulou $G$, Sanguedolce $F$, Brookman-May $S$, Akdogan $B$, Capitanio $U$, Roscigno $M$, Volpe $A$, Marszalek $M$, Uzzo R, Antonelli A, Langenhujisen J, Carini $M$, Minervini A, R Lane B. Assessment of volume preservation performed before or after partial nephrectomy accurately predicts postoperative renal function: Results from a prospective multicenter study.Urol Oncol 2019;37:33-39.

25. Kim SH, Kang KM, Yu A, Lee JH, Nam BH, Lee ES. A study of relationship of atheroembolic risk factors with postoperative recovery in renal function after partial nephrectomy in patients staged T1-2 renal cell carcinoma during median 4 year follow-up. Cancer Res Treat 2016;48:288-296.

26. Sejima T, Yumioka $T$, Yamaguchi $N$, Masago T, Morizane $S$, Hikita $K$, Honda M, Takenaka A. Cross-Sectional Investigations of Pre- and Post-Operative Renal Global Function and Renal Parenchymal Volumetry in Both Partial and Radical Nephrectomy Utilizing Film-Based Technology. Curr Urol 2019;12:127-133.

27. Lane BR, Russo $P$, Uzzo RG, Hernandez AV, Boorjian SA, Thompson RH, Fergany AF, Love TE, Campbell SC. Comparison of cold and warm ischemia during partial nephrectomy in 660 solitary kidneys reveals predominant role of nonmodifiable factors in determining ultimate renal function. J Urol 2011;185:421-427.

28. Simmons MN, Fergany AF, Campbell SC. Effect of parenchymal volume preservation on kidney function after partial nephrectomy. J Urol 2011;186:405-410.

29. Porpiglia F, Fiori C, Bertolo R, Angusti T, Piccoli GB, Podio V, Russo R. The effects of warm ischaemia time on renal function after laparoscopic partial nephrectomy in patients with normal contralateral kidney. World J Urol 2012;30:257-263.

30. Leppert JT, Lamberts RW, Thomas IC, Chung BI, Sonn GA, Skinner EC, Wagner TH, Chertow GM, Drooks JD. Incident CKD after Radical or Partial Nephrectomy. J Am Soc Nephrol 2018;29:207-216. 